〔特集：最新の電気泳動技術〕

\title{
超分子ヒドロゲルを支持体としたタンパク質電気泳動法の開発
}

\section{山中 正道}

\author{
静岡大学大学院理学研究科化学専攻
}

Development of protein electrophoresis using supramolecular hydrogel
Masamichi Yamanaka

E-mail: smyaman@ipc.shizuoka.ac.jp

(受付 2014 年 6 月 7 日, 受理 2014 年 6 月 14 日)

はじめに

タンパク質の電気泳動の歴史は, 1930 年代の Tiselius に よる自由溶液中における血清タンパク質の分離に端を発す る ${ }^{1)}$. その後, ゾーン電気泳動法としてゲルを支持体とする 電気泳動が開発された. ポリアクリルアミドゲルを支持体と するタンパク質の電気泳動は, 1959 年に初めて報告され, 半世紀以上が経過した現在においても, タンパク質の電気 泳動には不可欠な支持体として汎用されている2). 特に, 陰 イオン性界面活性剤であるドデシル硫酸ナトリウム(SDS) 存 在下で行うポリアクリルアミドゲル電気泳動法 (SDS-PAGE) は, 大学の研究室ではもちろん, 学生実験において行われ るほど一般的な技術として普及している. 化学者である著者 の視点から電気泳動の現状を眺めたとき,この分野はきわ めて成熟した領域に見えた。 ところが，これらの技術のユー ザーである生命科学者との会話から, 彼らは現状の電気泳 動法に必ずしも満足しているわけではないことがわかってき た.とりわけ，電気泳動後のタンパク質試料の回収につい ては, 煩雑かつ非効率的であることに不満を感じている研 究者が多いようであった。

そこで我々は, 生命科学者の不満を解消寸る新技術と して, ポリアクリルアミドゲルに代わり，低分子量化合物の 自己集合により構築される超分子ゲルを支持体とする電気 泳動法を着想した. 非共有結合を駆動力に形成する超分 子ゲルは，その形成と崩壊に高い可逆性を有することから， 電気泳動後の高効率的な試料回収が可能になると考えた. また，新規な支持体を電気泳動に適用することで，異なる 分離様式の発現も期待できる. さらには, ゲルの構成単位 となる低分子量化合物の分子設計に応じて, 様々なアフィ ニティー電気泳動の開発も可能になると考えた. 以下, 我々の開発した超分子ゲル電気泳動( SUGE: Supramolecular Gel Electrophoresis)について紹介寸る.

\section{界面活性剤により誘導される超分子ヒドロゲル ${ }^{3)}$}

我々は，ベンゼンを母核とする種々の三回対称トリスウ レア分子を合成し，それらが有機溶媒または水の中でゲル 化できることを見いだしてきた ${ }^{4)}$. 低分子七ドロゲル化剤とし ての機能を期待し，疎水性の三回対称トリスウレア分子に 親水基を導入した両親媒性分子 1 を低分子ヒドロゲル化剂 として設計，合成した(図1). 両親媒性分子 1 と水の混合 物は懸濁液になったが, ここに界面活性剂であるSDSを添 加すると超分子ヒドロゲルが得られた. 超分子ヒドロゲルの 形成において, SDS 濃度は重要であり, 適切な濃度以下で は懸濁液が，適切な濃度以上では透明な溶液がそれぞれ 得られた. また, 適切な濃度のSDSを添加し形成した超分 子ヒドロゲルにおいて, 添加するSDS の増加に伴いゲルの 透明度が向上寸ることが明らかとなった. ゲル化を誘導す る界面活性剂は, SDS に限定されることなく, 種々の陰イオ ン性界面活性剂, 陽イオン性界面活性剤も同様に機能し た.

キセロゲルの走査型電子顕微鏡 (SEM) 観測を行ったと ころ, 界面活性剂の濃度により繊維状集合体の太さに変化 が見られた. 界面活性剂濃度の上昇に伴い, 繊維状集合 体は細くなる.この結果より, 両親媒性分子 1 とイオン性界 面活性剂による超分子ヒドロゲルの形成メカニズムを以下 のように考察した. 両親媒性分子 1 は水中において自己集 合し，無秩序なバンドル化により不溶性の沈殿物を形成す る. イオン性界面活性剤の疎水部は, 繊維状集合体と疎 水性相互作用により会合寸る。 その結果, 繊維状集合体 表面に配置された界面活性剤の親水部の静電反発により, 過度なバンドル化が解消され超分子ヒドロゲルが形成され たと考えられる。 


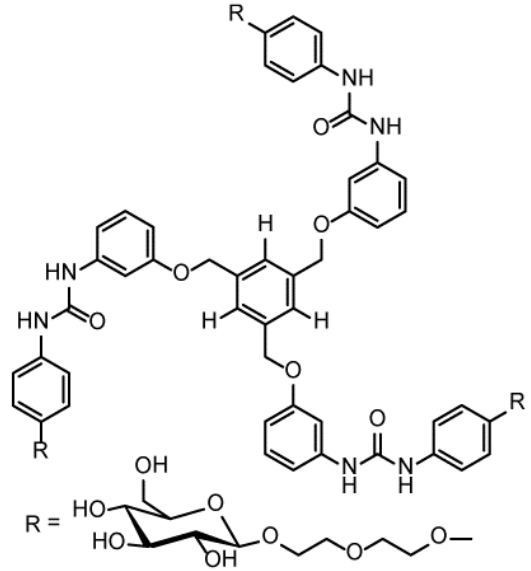

両親媒性分子 1

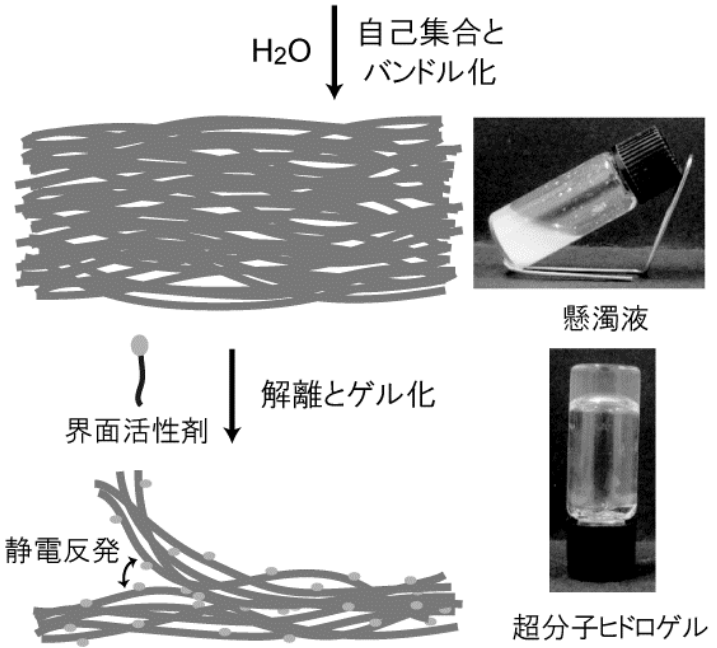

図 1 両親媒性分子 1 の構造式と、界面活性剤により誘導さ れるゲル化泳動

\section{超分子ヒドロゲルを支持体としたタンパク質試料の 電気泳動 ${ }^{5)}$}

両親媒性分子 1 は, 一般的な SDS-PAGEにおいて用い られる TGS 緩衝液(Tris: 25 mM; Glycine: 195 mM; SDS: $0.10 \%$ \%)ゲル化した. そこで，この超分子ヒドロゲルを支持 体としたタンパク質試料の電気泳動を検討することとした (図2)。種々の検討結果により, 以下に示寸実験手順を確 立した．1）超分子ヒドロゲルをガラスキャピラリーに充填す る ( $\phi 2 \mathrm{~mm}, 8 \mathrm{~cm})$. 電気泳動後のゲルの操作において十 分な物理的強度が必要であるため, $2.0 \mathrm{wt} \%$ の両親媒性分 子 1 に $2.0 \mathrm{wt} \%$ のアガロースを加えた超分子ヒドロゲルを用 いた. ただし, アガロースのみではタンパク質試料は電気 泳動により分離されない．2)超分子ヒドロゲルを充填した ガラスキャピラリーの一端にタンパク質試料を充填する. 3) サブマリン型電気泳動装置を用い電気泳動を行う。移動相 には TGS 緩衝液を用い, $100 \mathrm{~V}$ で 150 分前後電気泳動す る. 4)キャピラリーからゲルを取り出し, 8 等分に分割する. 5) 分割したゲルよりタンパク質試料を抽出する. 6) 抽出し
た溶液を SDS-PAGE, 続いて CBB 染色することで, 超分 子ヒドロゲル中でのタンパク質の分離様式を解析する.

5)の抽出条件を種々検討した結果, 電気泳動後のゲルに 緩衝液を加え遠心分離を行うといらきわめて単純な操作で, 50\%程度のタンパク質が抽出されることが明らかとなった。 同様の操作にて，ポリアクリルアミドゲルからタンパク質の 抽出を行っても, タンパク質はほとんど抽出されなかった. 超分子七ドロゲルは，可逆的な構造変化が可能であるため, 遠心分離の際に, 集合体構造が崩壊し効率的にタンパク 質が抽出されたと考察している.

超分子ヒドロゲルを支持体とした電気泳動(SDS-SUGE) で, 種々の分子量のタンパク質試料 $(6.5 \mathrm{kDa}-116 \mathrm{kDa})$ を用いて検討した。 $\beta$-ガラクトシダーゼ $(116 \mathrm{kDa})$ とオブ アルブミン $(45 \mathrm{kDa})$ の混合物を電気泳動したところ， $\beta$-ガ ラクトシダーゼは 6〜8 レーンに検出され, オブアルブミン はより陽極側の 4〜 7レーンに検出された. 分子量の小さな オブアルブミンがより陽極側に移動する分離様式は，既存 のSDS-PAGE と同様であった. ところが, 分子量が $45 \mathrm{kDa}$ (オブアルブミン)よりも小さな分子量のタンパク質を用いた 超分子ゲル電気泳動では, SDS-PAGE とは異なり, 分子量 の小さなタンパク質ほじ陽極側への移動度が小さくなる分 離様式が見いだされた. 例えば, オブアルブミン (45 kDa) とアプロチニン $(6.5 \mathrm{kDa})$ の混合物を電気泳動したところ, オブアルブミンは 3〜 5レーンに検出され, アプロチニンは より陰極側の 7 レンに検出された. リゾチーム $(14.4 \mathrm{kDa})$ とアプロチニンの電気泳動では, リゾチームが 4, 5 レーン に検出され，アプロチニンは 6 レーンに検出された. 一般 的に, SDS-PAGE は, 低分子量のタンパク質の分離を不得 手としているが, SDS-SUGE では, わずか 2.0 wt\%のゲルで $15 \mathrm{kDa}$ 未満のタンパク質の分離を達成した。この SDS-SUGEにおいては, 一般的な電気泳動に見られる分 子ふるい効果」と「ゲル濾過などに見られる分子ふるい効 果」という2 種類の分子ふるい効果が機能し，このような特 徵的な分離様式が発現したと考察している.

\section{おわりに}

我々は, タンパク質の電気泳動における新規な支持体 として，超分子ヒドロゲルが適用可能であることを示した． SDS-SUGE においては, SDS-PAGE では見られない特異 な分離様式や，高効率的なタンパク質試料の回収などの 優れた特性も示すことができた. 現在は, 未変性タンパク 質の電気泳動へと, 超分子ヒドロゲルの適用範囲を拡大寸 ベく検討を行っている.

タンパク質電気泳動の支持体として，超分子ヒドロゲル は多くの可能性を秘めている. しかし, 生命科学者が汎用 できる技術として確立するためには，まだまだ多くの課題 
が残されている．半世紀にわたり世界中で利用される PAGEからすると，産声をあげたばかりのSUGEはまだまだ 未熟である. しかし, SUGEの可能性を信じ, この技術を成 熟させ，電気泳動の選択肢として生命科学者が SUGE を チョイスできる日を目指したい.
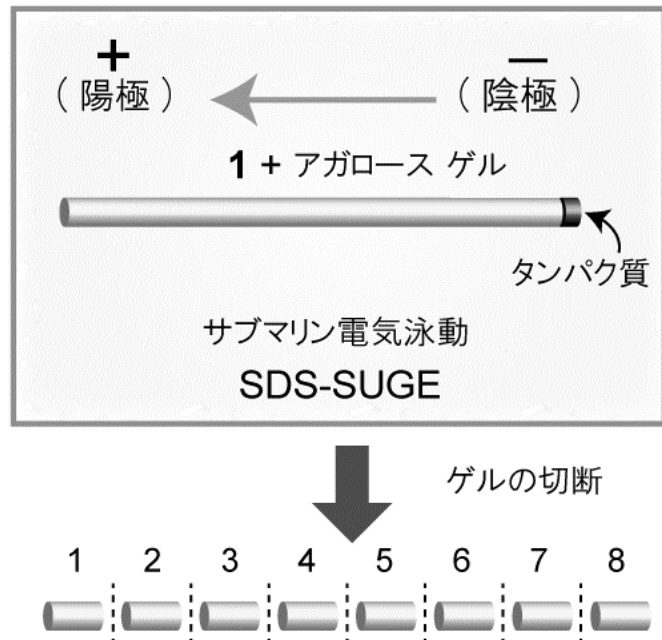

抽出

\section{SDS-PAGE（分析）}

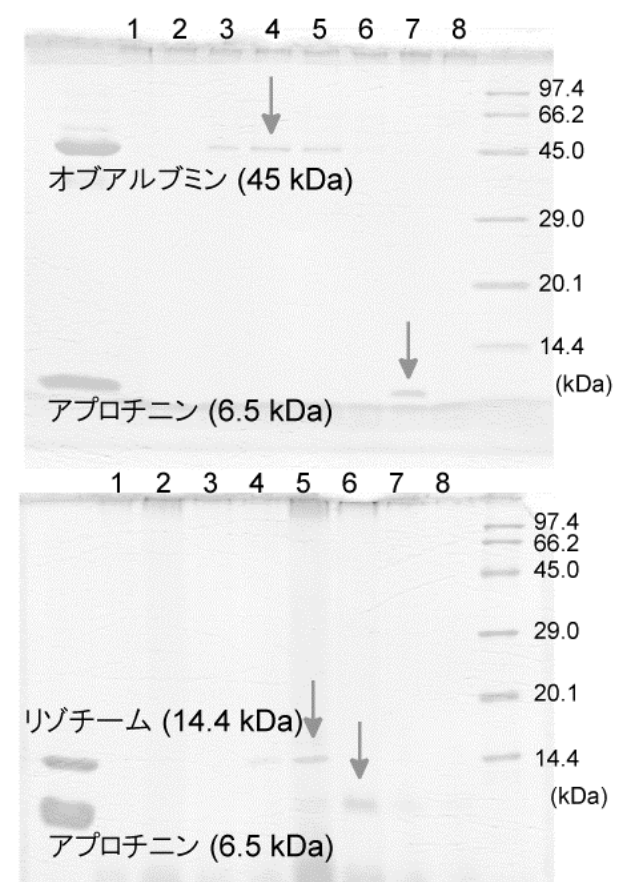

図 2 超分子ゲル電気泳動 (SDS-SUGE) の手順と, タン パク質の分離様式

\section{文 献}

1) Tiselius A. Electrophoresis of serum globulin. I. Biochem J. 1937; 31: 313-317.

2) Raymond S, Weintraub L. Acrylamide gel as a supporting medium for zone electrophoresis. Science 1959; 130: 711.

3) Jinno Y, Yamanaka M. Ionic surfactants induce amphiphilic tris(urea) hydrogel formation. Chem Asian J. 2012; 7: 1768-1771.

4) a) Yamanaka M, Nakamura T, Nakagawa T, Itagaki H. Tetrahedron Lett. 2007; 48: 8990-8993; b) Yamanaka M. J Incl Phenom Macrocycl Chem. 2013, 77, 33-48 (Review).

5) Yamamichi S, Jinno Y, Haraya N, Oyoshi T, Tomitori H, Kashiwagi K, Yamanaka M. Separation of proteins using supramolecular gel electrophoresis. Chem Commun. 2011; 47: 10344-10346. 